\title{
EFFECT OF 1,6-HEXAMETHYLENE DIISOCYANATE EXPOSURE ON PEAK FLOWMETRY IN AUTOMOBILE PAINT SHOP WORKERS IN IRAN
}

\author{
Siyamak POURABEDIAN ${ }^{1}$, Abdullah BARKHORDARI ${ }^{1}$, Ehsanallah HABIBI ${ }^{1}$, \\ Masoud RISMANCHIYAN ${ }^{1}$, and Mohsen ZARE $^{2}$ \\ Department of Occupational Health, Faculty of Health, Isfahan University of Medical Sciences Isfahan ${ }^{1}$, Department \\ of Occupational Health, Faculty of Health, Shahid Sadoughi University of Medical Sciences Yazd', Iran
}

Received in August 2009

Accepted in February 2010

\begin{abstract}
The aim of this study was to investigate the effects of occupational exposure to 1,6-hexamethylene diisocyanate (HDI) on peak flowmetry in automobile body paint shop workers in Iran. We studied a population of 43 car painters exposed to HDI at their workplaces. Peak expiratory flow was tested for one working week, from the start to the end of each shift. Air was sampled and HDI analysed in parallel, according to the OSHA 42 method.

Daily and weekly HDI exposure averages were $(0.42 \pm 0.1) \mathrm{mg} \mathrm{m}^{-3}$ and $(0.13 \pm 0.05) \mathrm{mg} \mathrm{m}^{-3}$, respectively. On painting days, $72 \%$ of workers showed more than a $10 \%$ variation in peak expiratory flow. Inhalation exposure exceeded the threshold limit value (TLV) ten times over. This strongly suggests that HDI affected the peak flowmetry in the studied workers.
\end{abstract}

KEY WORDS: air, occupational exposure, respiratory symptoms, sensitizer, time-weighted average

Asthma rates are getting higher in all parts of Iran and $10 \%$ of Iranian people suffer from asthma (1). Some chemicals, isocyanides among them, are known respiratory sensitisers, which at low concentrations are associated with occupational asthma in the developed countries $(2,3)$.

Diisocyanates are compounds with low molecular weight and high reactivity, that have an $\mathrm{N}=\mathrm{C}=\mathrm{O}$ group. The most commonly applied isocyanides are toluene diisocyanates (TDI), 4,4-diphenyl methane diisocyanates (MDI) and 1,6-hexamethylene diisocyanate (HDI). They are used in the production of polyurethane foam, elastomers, adhesives, paints, and surface coatings (4-5). They are common in workshops with a small number of workers (4) such as automobile body paint workshops, which use a lot of paint, primer, and coatings containing HDI.
The most common routes of diisocyanates exposure are the respiratory tract and skin (6). These compounds take form of the mist, vapour, or aerosol, depending on the type (7). Skin contact can occur via contaminated surfaces (8). The American Conference of Governmental Industrial Hygienists (ACGIH) set the eight-hour time-weighted average threshold limit value (TLV-TWA) for HDI in the air to $34 \mu \mathrm{g}$ $\mathrm{m}^{-3}(9)$. The NIOSH recommended exposure limit (REL) for HDI is $140 \mu \mathrm{g} \mathrm{m}^{-3}$ as a 10-minute ceiling limit and $35 \mu \mathrm{g} \mathrm{m}^{-3}$ as an 8-hour TWA (10). HDI is used as an activator in paints, because it has a special characteristic that is different from other aromatic isocyanates like methylene diisocyanate (MDI) and toluene diisocyanate (TDI) (11). HDI is the most toxic when it takes the form of aerosol (12). This form is the most common in car body paint shops in Iran. 
Diisocyanates and polyisocyanates affect the respiratory system in a number of ways including irritation, asthma, hypersensitivity pneumonitis, and asymptomatic acceleration with decreased lung function $(13,14)$. Various studies have indicated that exposure to relatively low concentrations of isocyanides is related to impaired lung function (15).

Monitoring exposure to these chemicals in car body paint shops presents a number of difficulties because each shop employs a small number of workers, work practices are inconsistent, and exposure is irregular (5). In addition, medical surveillance and occupational hygiene programmes for these workers are usually inadequate (7). Small factory workers exposed to isocyanides seem to have significantly higher prevalence of respiratory symptoms than controls (16). Occupational asthma is estimated to range between $5 \%$ and $30 \%(4,17-19)$. In a study conducted in Iran, respiratory symptoms in MDI-exposed workers were significantly elevated (20).

This cross sectional study investigated HDI exposure in automobile body paint shops and variation in peak expiratory flow in exposed workers on different working days. The aim was to see if there was a relation between the two.

\section{METHODS}

\section{Population description}

The exposed population included 43 randomly selected workers employed in automobile body paint shops. Their mean age was $(37.9 \pm 8.89)$ years (range: 23 to 60 years), and work experience $(13.39 \pm 6.85)$ years (range: 3 to 30 years).

Each worker was interviewed using a questionnaire, which included personal data and respiratory signs and symptoms. This questionnaire was specifically designed for this study. It passed the validity and reliability test for this investigation. Exclusion criteria were respiratory disorders including asthma, cigarette smoking, and use of respiratory drugs. All subjects were healthy on enrolment.

\section{Peak flowmetry}

All workers took peak flowmetry (4) tests with the Asma Plan Vitalograph ${ }^{\dot{O}}$ apparatus (UK) two times a day, at the start and end of each work shift, over one week. Changes in peak flowmetry were calculated for each worker. The recorded value was the maximum of three attempts during each test. To obtain daily variation in peak flow, we used each subject as his own control. We simply compared the calculated normal peak flow based on the worker's age, height, and weight with the maximum peak flow taken at the start and the end of each shift. According to the American Thoracic Society (ATS), a decrease of more than $20 \%$ suggests respiratory impairment (21).

\section{Sampling and analysis of HDI}

For HDI sampling and analysis we used high performance liquid chromatography (HPLC), relying on the OSHA 42 method (7). A solution containing $3.5 \mathrm{~g}$ HDI (95\%, Sigma-Aldrich, USA) in $25 \mathrm{~mL}$ methylene chloride (Merck, Germany) was slowly added to $100 \mathrm{~mL}$ of $72.5 \mathrm{mg} \mathrm{mL}^{-1}$ methylene chloride solution of 1-(2-pyridyl) piperazine (1-2PP, SigmaAldrich, USA). The obtained solution was kept at $35^{\circ} \mathrm{C}$ for $10 \mathrm{~min}$ and the volume of methylene chloride was reduced to approximately $10 \mathrm{~mL}$ by nitrogen current. The resulting solution was adsorbed by hexane (Sigma-Aldrich, USA), filtered, and again dissolved in a small amount of methylene chloride. This solution was again adsorbed, filtered, and washed with hexane. Ultimately, $9 \mathrm{~g}$ of product was obtained after drying in a vacuum. This product was dissolved in dimethyl sulphoxide (Merck, Germany) and injected in the HPLC (Jasco Corp., Japan) to determine its standard peak. In order to obtain the calibration curve, three samples with concentrations of $3.3 \mu \mathrm{g} \mathrm{mL}^{-1}$, $6.6 \mu \mathrm{g} \mathrm{mL}^{-1}$, and $13.2 \mu \mathrm{g} \mathrm{mL}^{-1}$ were used in a HPLC with a UV detector and a C8 column (Supelco, USA) at $40{ }^{\circ} \mathrm{C}$. The chromatography was reverse phase and its mobile phase was a $30 \%$ Astonitril solution. The flow rate was $1 \mathrm{~mL} \mathrm{~min}^{-1}$. Related chromatograms were determined and a calibration curve plotted.

In order to determine HDI concentration in ambient air, sampling pumps (SKC Company, USA) were calibrated to the flow rate of $1 \mathrm{~L} \mathrm{~min}^{-1}$. Then, $37 \mathrm{~mm}$ glass fibre filters were coated with $0.1 \mathrm{mg}$ of 1-2PP and placed with backup pads in three-piece cassettes. According to OSHA recommendation, $15 \mathrm{~L}$ of air in the breathing zone was sampled and samples sent to the laboratory for HPLC analysis. In the laboratory, the pollutants were extracted using $2 \mathrm{~mL}$ of 90:10 acetonitrile:dimethyl sulphoxide mixture (Merck, Germany) and injected in the HPLC. The limit of detection was $0.32 \mu \mathrm{g} \mathrm{kg}^{-1}$. 


\section{Statistical analysis}

The obtained data were analysed with the software package SPSS, version 11.5, applying Student's $t$ test and Pearson's correlation coefficient to test the differences between variables. A P value of less than 0.05 was considered statistically significant.

\section{RESULTS}

The workers were not evenly exposed to HDI during the day, and the mean daily exposure was 15 minutes. Table 1 shows the minimum, maximum, and mean time of daily and weekly exposure to HDI. For each worker, we calculated the timeweighted average (TWA). The mean daily HDI (TWA) air concentration in the breathing zone was $(0.42 \pm 0.1) \mathrm{mg} \mathrm{m}^{-3}$. The 8-hour TLV-TWA for HDI is $0.034 \mathrm{mg} \mathrm{m}^{-3}$ of air (9). The mean weekly HDI (TWA) was $(0.13 \pm 0.059) \mathrm{mg} \mathrm{m}^{-3}$.

Table 2 shows daily decreases in peak flow over the working week; they increase from the start and are the highest in the middle of the week. In this study, mean weekly decrease in peak flow was compared with the expected (normal) peak flow (Figure 1). Figure 2 shows the decrease in the peak flow on the day of painting and the day after. Mean peak flow decreases on the day of painting were $11.2 \%$ and $7.9 \%$ the day after $(\mathrm{P}<0.001)$. Mean peak flows at the start of the shift on the day of painting and the following day were $537.8 \mathrm{~L} \mathrm{~min}^{-1}$ and $518.9 \mathrm{~L} \mathrm{~min}^{-1}$, respectively. At the end of the shift, they were $479.1 \mathrm{~L} \mathrm{~min}^{-1}$ and
478.2 $\mathrm{L} \mathrm{min}^{-1}$, respectively. The difference between these two days was statistically significant $(\mathrm{P}=0.017$; Figure 3).

Figure 4 shows the mean percentage of changes in peak flow on the day of painting and the day after according to work experience. The mean decrease in peak flow (expressed in percentage) correlated with work experience; the longer work experience, the greater the percentage of decrease in peak flow.

HDI concentration also correlated well with the percentage of decrease in peak flow on the day of painting and also with the mean peak flow on the day of painting $(\mathrm{P}<0.001)$. The coefficient ratios (r) were 0.884 and 0.664 , respectively. The percentage of decrease in peak flow on the day of painting significantly correlated with age and work experience $(\mathrm{P}<0.001)$. The coefficient ratios were 0.661 and 0.719 , respectively. Similarly, the mean weekly decrease in peak flow, as compared to normal peak flow, significantly correlated with age and work experience $(\mathrm{P}<0.001)$. The coefficient ratios were 0.746 and 0.828 , respectively.

\section{DISCUSSION}

Our study has shown that on painting days, Iranian car paint shop workers were exposed to HDI concentrations over ten times the 8-hour TLV-TWA $\left[(0.42 \pm 0.1) \mathrm{mg} \mathrm{m}^{-3}\right.$ vs. $\left.0.034 \mathrm{mg} \mathrm{m}^{-3}\right]$. However, as most of them did painting jobs one to two days a week, their weekly exposure was lower [mean weekly

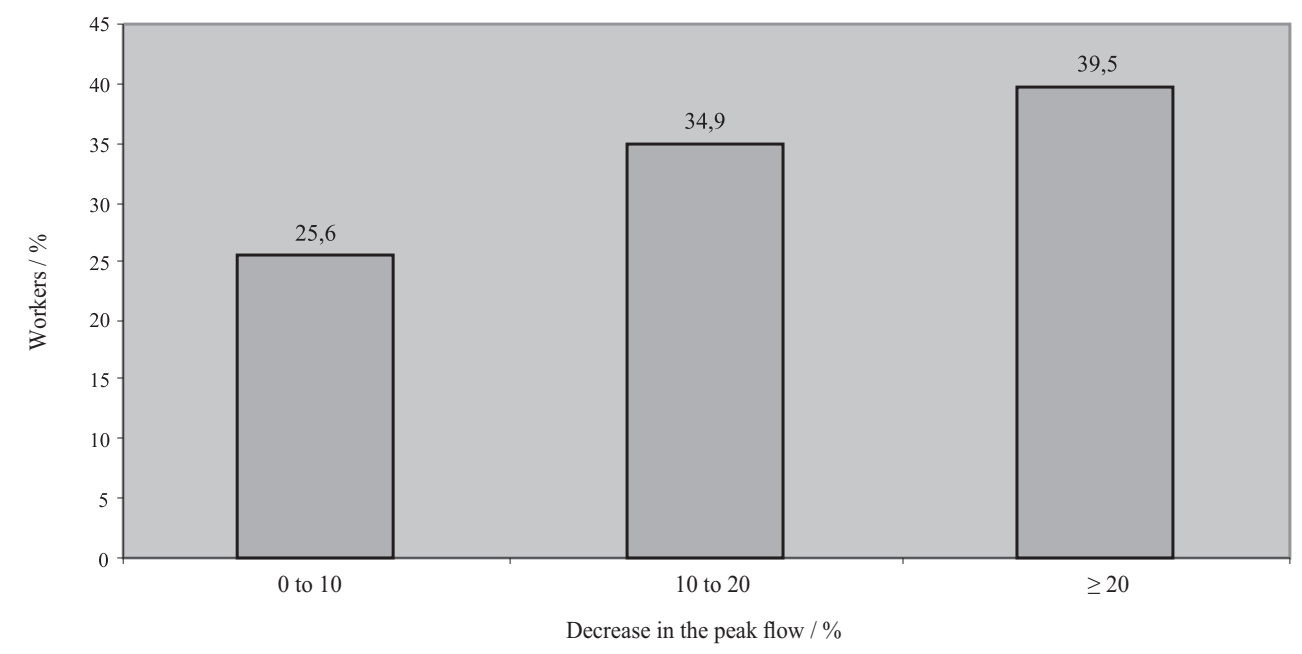

Figure 1 Distribution of exposed workers with respect to decrease in mean weekly peak flow 


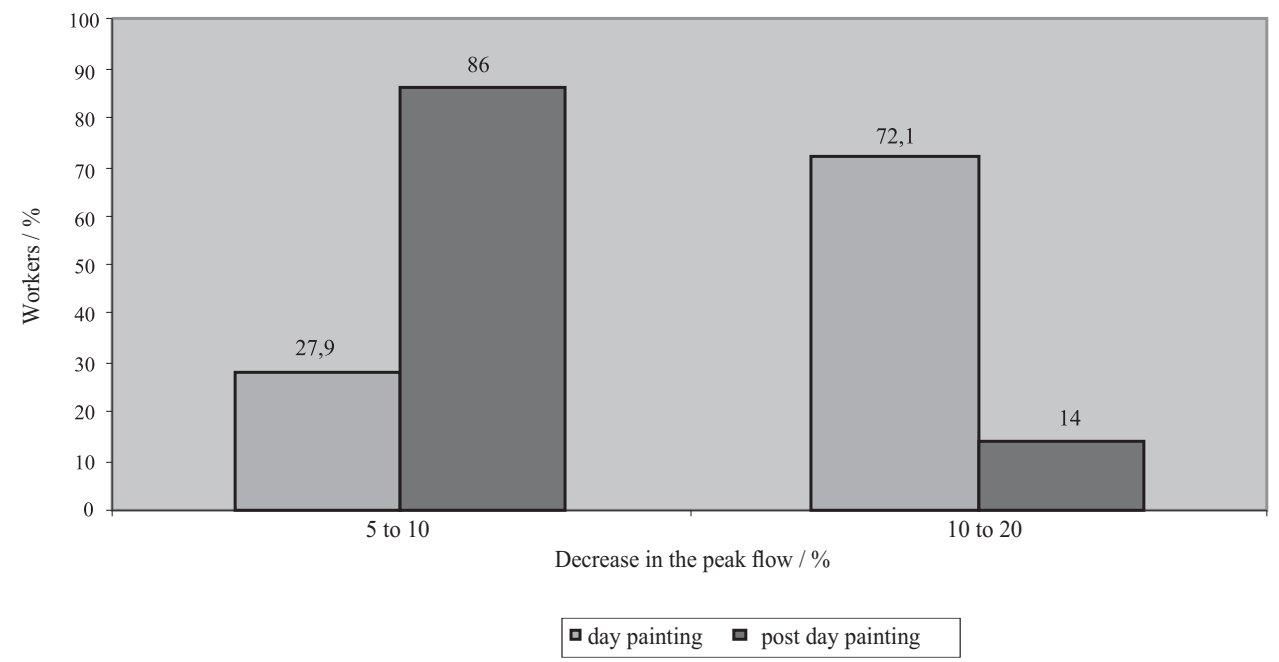

Figure 2 Distribution of exposed workers with respect to changes between peak flow recorded at the start of the work shift on the day of painting and at the end of the work shift on the day after exposure

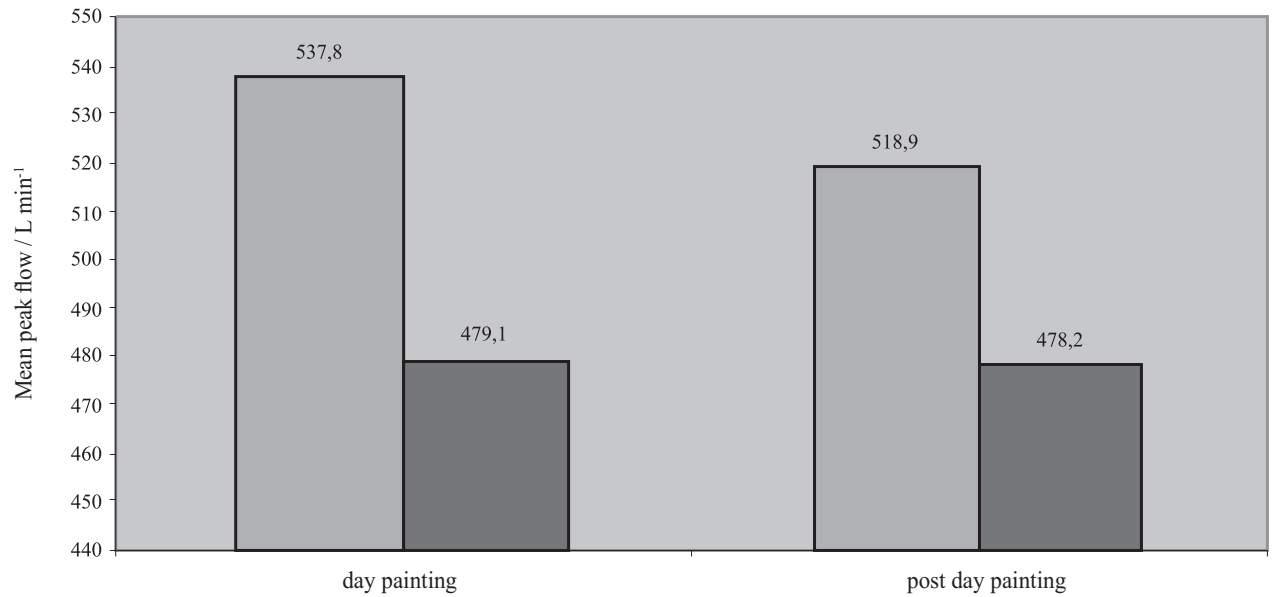

$\square$ mean peak of worker at the start of work shift $\square$ mean peak flow of worker at the end of work shift

Figure 3 Mean peak flow of workers at the start and end of each work shift on the day of painting and the day after

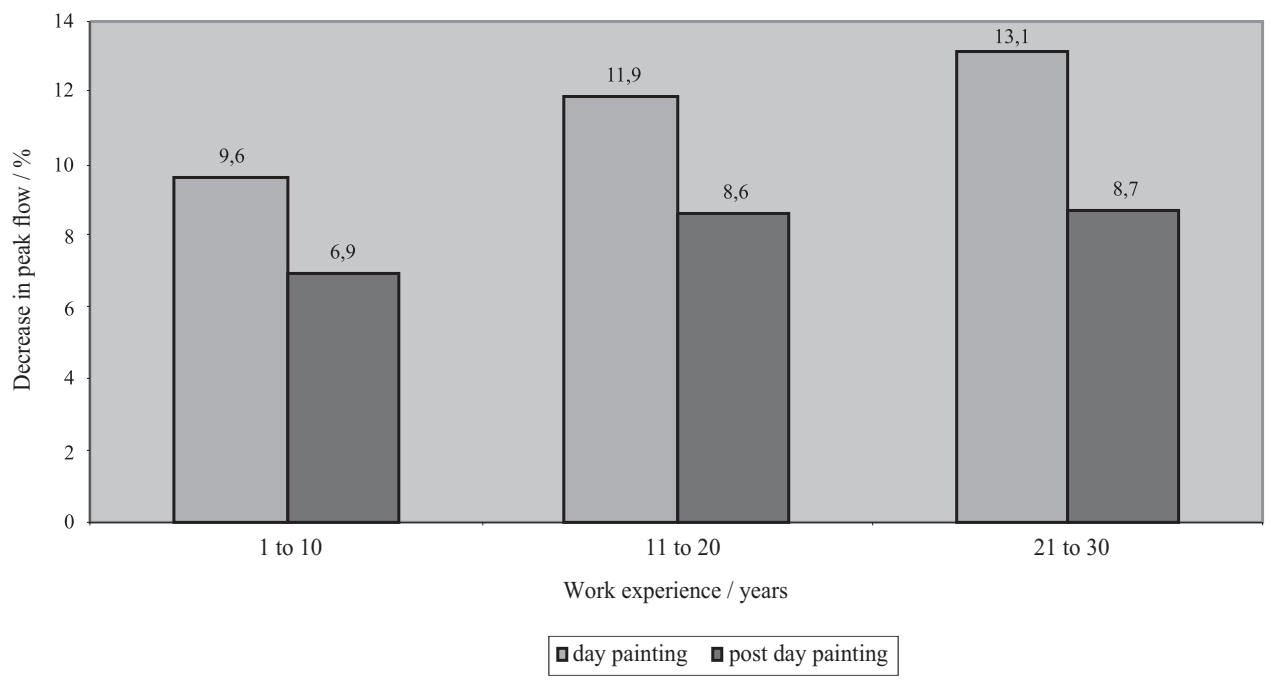

Figure 4 Mean percentage of changes in peak flow on the day of painting and the day after by years at work 
Table 1 Daily and weekly exposure of workers $(N=43)$ to 1,6-hexamethylene diisocyanate

\begin{tabular}{lcc}
\hline TWA & \multicolumn{2}{c}{$\mathbf{1 , 6 - H e x a m e t h y l e n e ~ d i i s o c y a n a t e ~} / \mathbf{~ m g ~}^{-3}$} \\
& Range & Mean \pm SD \\
\hline Daily & 0.26 to 0.79 & $0.42 \pm 0.10$ \\
\hline Weekly & 0.04 to 0.27 & $0.13 \pm 0.06$ \\
\hline
\end{tabular}

$T W A=$ time-weighted average

Table 2 Changes in daily peak flow recorded in workers ( $N=43)$ exposed to 1,6-hexamethylene diisocyanate

\begin{tabular}{lllllll}
\hline & \multicolumn{7}{c}{ Days of the working week } \\
\hline & Sat & Sun & Mon & Tue & Wed & Thu \\
\hline Changes in peak flow $/ \%$ & 6.90 & 7.20 & 8.68 & 8.82 & 8.59 & 8.10 \\
\hline SD & 3.25 & 2.90 & 2.30 & 2.80 & 2.50 & 1.95 \\
\hline
\end{tabular}

TWA $\left.(0.13 \pm 0.059) \mathrm{mg} \mathrm{m}^{-3}\right]$. In a study by Woskie et al. (9), the HDI air concentration in automobile paint shops was $0.206 \mathrm{mg} \mathrm{m}^{-3}$. In a study by Torling et al. (15), it was $0.0015 \mathrm{mg} \mathrm{m}^{-3}$. In a study by Liu et al (8), it ranged from $0.002 \mathrm{mg} \mathrm{m}^{-3}$ to $0.116 \mathrm{mg} \mathrm{m}^{-3}$, and the concentrations were below TLV in only two workshops. These results are consistent with ours, whereas those by Torling et al. are not.

The percentage of decrease in daily peak flow of exposed workers in our study grew toward the middle of the week, as most painting jobs were done by that time. Most of the workers showed a decrease of over $20 \%$ in respect to what would have been their normal peak flow. However, we can not say that this variation is related to HDI alone, because there are other contaminants at their workplace, such as organic solutions, which can cause a variation in the peak flow.

A study by Wink et al. (22) showed that mean peak flow in workers decreased on the day of exposure and increased on days when the workers were away from work. In our study, the mean peak flow at the end of the shift on the day of painting was significantly lower than at the start of the shift, which may be related to HDI exposure. The effects of exposure remained till the day after painting. Hauser et al. (23) also found that peak flow at the end of the shift was lower than at the start of the shift. Glindmeyer et al. (14) showed that exposure to isocyanates significantly correlated with decreased expiratory flow. Similarly, Yorgancioğlu et al. (4) explained that polyurethane foam production workers exposed to isocyanates had lower $\mathrm{FEV}_{1}$ and FVC levels than workers in other production lines. In an Iranian study, Mortezavi et al. (21) obtained similar results as Yorgancioğlu et al. (4).

In our study, we have established a significant correlation between HDI and mean peak flow. This correlation is also significant between the mean percentage of changes in peak flow on the day of painting and HDI. This suggests that higher HDI levels reduce mean peak flow by the end of the painting day, rendering daily variation (decrease) significantly greater than on non-painting days. Similar to our results, Shabani et al. (24) also found a significant difference between changes in peak flow among automobile paint shop workers on the day of painting and the day after that. A study by Torling et al. (15) suggested that respiratory damage and complications in automobile paint shop workers was due to exposure to HDI.

In our study, we also found a significant correlation between changes in peak flow on the day of painting and age and between changes in peak flow and work experience. In other words, older workers showed greater variety in peak flow than young and less experienced workers. In a study of worker exposure in a cleaning agent manufacturer, Neukrich et al. (25) observed that variations in the peak flow were directly related to age.

\section{CONCLUSION}

The concentration of HDI found in our study was well above the acceptable limits for automobile paint shops, and there are grounds to believe that it affected 
the peak flow in our workers. This calls for engineering and management measures that should reduce the level of workers' exposure to HDI.

\section{Acknowledgement}

The authors acknowledge and thank the head of the research department of Isfahan Medical University for granting the budget and equipment required for the study. The authors also wish to thank all those who helped them in the study and to honour the memory of the late Professor Mohsen Rahiminejhad.

Grant sponsor was the Research Department of Isfahan Medical University (Grant number 387102)

\section{REFERENCES}

1. Pedram Razi SH, Basampour S, Kazemnejad A. [The quality of life in asthma patients, in Persian]. HAYAT 2007;13:2934.

2. Chan-Yeung M, Malo JL. Occupational asthma. New Engl J Med 1995;333:107-12.

3. National Institute for Occupational Safety and Health (NIOSH). NIOSH ALERT - Preventing asthma and death from diisocyanate exposure. DHHS Publication No. 96-111. Cincinnati (OH): NIOSH; 1996.

4. Yorgancıoğlu A, Şakar A, Keskin T, Dinç G, Çelik P. Respiratory symptoms and occupational asthma in polyurethane foam production workers. Turk Respir J 2002;3:19-23.

5. Redlich CA, Stove MH, Coren BA, Wisnewski AV, Holm CT, Cullen MR. Diisocyanate-exposed auto body shop worker: a one year follow-up. Am J Ind Med 2002;42:5118.

6. Tarlo SM, Balmes J, Balkissoon R, Beach J, Beckett W, Bernstein D, Blanc PD, Brooks SM, Cowl CT, Daroowalla F, Harber P, Lemiere C, Liss GM, Pacheco KA, Redlich CA, Rowe B, Heizer J. Diagnosis and management of workrelated asthma. Chest 2008;134(Suppl 3):1S-41S.

7. Occupational Safety and Health Administration (OSHA) OSHA Method no. 42: Diisocyanate [displayed 26 March 2010]. Available at http://www.osha.gov/dts/sltc/methods/ organic/org042/org042.html.

8. Liu Y, Sparer J, Woskie SR, Cullen MR, Chung JS, Holm CT, Redlich CA. Qualitative assessment of isocyanate skin exposure in auto body shops: a pilot study. Am J Ind Med 2000;37:265-74.

9. Woskie SR, Sparer J, Gore RJ, Stowe M, Bello D, Liu Y, Youngs F, Redlich CA, Eisen E, Cullen M. Determinants of isocyanates exposures in auto body repair and refinishing shops. Ann Occup Hyg 2004;48:393-403.

10. Musk AW, Peters JM, Wegman DH. Isocyanides and respiratory disease: current status. Am J Ind Med 2007;13:33149.
11. Agency for Toxic Substances and Disease Registry (ATSDR). Toxicological profile for hexamethylene diisocyanate (HDI). Atlanta (GA): U.S. Department of Health and Human Services, Public Health Service; 1998.

12. Alexandersson R, Plato N, Kolmodin-Hedman B, Hedenstierna G. Exposure, lung function, and symptoms in car painter exposed to hexamethylene diisocyanate and biuret modified hexamethylene diisocyanate. Arch Environ Health 1987;42:367-73.

13. American Conference of Governmental Industrial Hygienists (ACGIH). TLVs and BEIs. Threshold Limit Values for Chemical Substances and Physical Agents. Biological Exposure Indices. Cincinnati (OH): ACGIH; 1999.

14. Glindmeyer HW, Lefante Jr JJ, Rando RJ, Freyder L, Henizdo E, Jones RN. Spray painting and chronic air ways obstruction. Am J Ind Med 2004;46:104-11.

15. Torling G, Alexandersson R, Hedestierna G, Plato N. Decreased lung function and exposure to diisocyanates (HDI and HDI- BT) in car repair painter: observation and re- examination 6 years after initial study. Am J Ind Med 2007;17:299-310.

16. Sari-Minodier I, Charpin D, Signouret M, Poyen D, Vervloet D. Prevalence of self reported respiratory symptoms in worker exposure to isocyanate. J Occup Environ Med 1999;41:582-8.

17. Franklin PJ, Goldenberg WS, Ducatman AM, Franklin E. Too hot to handle: unusual exposure of HDI in specialty painters. Am J Ind Med 2000;37:431-7.

18. Pronk A, Tielemans E, Skarping G, Bobeldijk I, Hemmen VJ, Heederik D, Preller L. Inhalation exposure to isocyanides of car body repair shop workers and industrial spray painters. Ann Occup Hyg 2006;50:1-14.

19. Vandenolas O, Delwich JP, Staquet P, Jamart J, Bernard A, Boulanger J, Delaunois L, Sibille Y. Pulmonary effect of short-term exposure to low level of toluene diisocyanates in asymptotic subject. Eur Respir J 1999;13:1144-50.

20. Mortezavi SB, Jabbari-Gharabagh M, Asilian H, Khavanin A, Solimanian A. [Evaluation of 4,4-methylene diphenyl diisocyanates effects on foam producing workers of car manufacture, in Persian]. J Qazvin Univ Med Sci 2005;34:4350.

21. American Thoracic Society (ATS). Standardization of spirometry. Am J Respir Crit Care Med 1995;152:110736.

22. Winck JC, Delgado L, Vanzeller M, Guimaraes T, Torres S, Apage JM. Monitoring of peak expiratory flow rates in cork workers' occupational asthma. J Asthma 2001;38:357-62.

23. Hauser R, Daskalakis C, Christiami DC. A regression approach to the analysis of serial peak flow among fuel oil ash exposed workers. Am J Respir Crit Care Med 1996;154:97480.

24. Shabanian VR. Study of the changes in lung function tests of automobile paint workshop workers in the city of Isfahan. Isfahan: Medical University of Sciences; 2007.

25. Neukrich F. Peak expiratory flow variability and bronchial responsiveness to metacholine. Am Rev Respir Dis 1992;146:71-5. 


\section{Sažetak}

\section{UTJECAJ IZLOŽENOSTI 1,6-HEKSAMETILEN DIIZOCIJANATU (HDI) NA VRŠNI EKSPIRATORNI PROTOK U AUTOLAKIRERA U IRANU}

Cilj je ovog ispitivanja bio utvrditi vršni protok u 43 iranska autolakirera profesionalno izložena 1,6heksametilen diizocijanatu (HDI). Vršni ekspiratorni protok testiran je tjedan dana na početku i kraju svake smjene. Uzorkovanje i mjerenje HDI-ja u zraku radilo se istodobno s testiranjem vršnoga protoka, prema metodi OSHA 42.

Prosječna dnevna izloženost radnika HDI-ju iznosila je $(0.42 \pm 0.1) \mathrm{mg} \mathrm{m}^{-3}$, a tjedna $(0.13 \pm 0.05) \mathrm{mg} \mathrm{m}^{-3}$. U $72 \%$ radnika vršni ekspiratorni protok tijekom dana varirao je više od $10 \%$.

Radnici su udisali deset puta više razine HDI-ja od graničnih te je moguće da je HDI utjecao na mjerenja plućne funkcije.

KLJUČNE RIJEČI: kemijski alergen, profesionalna izloženost, respiracijski simptomi, vremenski ponderirani prosjek, zrak

\section{CORRESPONDING AUTHOR:}

Mohsen Zare

Department of Occupational Health, Faculty of Health Shahid Sadoughi University of Medical Sciences

Yazd, Iran

E-mail: Mohsen.1914@gmail.com 